\title{
Chirocentrodon bleekerianus \\ (TELEOSTEI: CLUPEIFORMES: PRISTIGASTERIDAE), A SMALL PREDACEOUS HERRING WITH FOLDED AND DISTINCTIVELY ORIENTED PREY IN STOMACH
}

\author{
SAZIMA, C., ${ }^{1,3}$ MOURA, R. L. ${ }^{2}$ and SAZIMA, I. ${ }^{1}$ \\ ${ }^{1}$ Departamento de Zoologia e Museu de História Natural, Universidade Estadual de \\ Campinas, C.P. 6109, CEP 13083-970, Campinas, SP, Brazil \\ ${ }^{2}$ Seção de Peixes, Museu de Zoologia, Universidade de São Paulo, CEP 04299-970, São Paulo, SP, Brazil \\ ${ }^{3}$ Departamento de Zoologia, Universidade Estadual Paulista, Av. 24-A, 1515, C.P. 199, \\ CEP 13506-900, Rio Claro, SP, Brazil \\ Correspondence to: Cristina Sazima, Departamento de Zoologia e Museu de História Natural, Universidade \\ Estadual de Campinas, C.P. 6109, CEP 13083-970, Campinas, SP, Brasil, e-mail: sazimacris@yahoo.com \\ Received January 20, 2003 - Accepted February 18, 2003 - Distributed February 29, 2004
}

(With 2 figures)

\begin{abstract}
Predaceous fish-eating species of the order Clupeiformes have a large mouth with well-developed teeth, and reach the greatest sizes within their families (up to $90 \mathrm{~cm}$ ). We found that the pristigasterid Chirocentrodon bleekerianus, a small clupeiform (about $10 \mathrm{~cm}$ ) from the tropical SW Atlantic, is able to prey on proportionally large clupeoid fishes and caridean shrimps. Fish preys are folded in the stomach of this herring, their heads and tails pointing toward the predator's head. This distinctive orientation of fish prey is also recorded for some small to medium-sized, fish-eating species of the tropical freshwater order Characiformes with canine-like teeth similar to those found in C. bleekerianus.
\end{abstract}

Key words: Clupeiformes, predaceous habits, piscivory, folding of prey, convergence.

\section{RESUMO}

\section{Chirocentrodon bleekerianus (Teleostei: Clupeiformes: Pristigasteridae), uma sardinha predatória de pequeno porte que apresenta suas presas dobradas e orientadas no tubo digestivo}

Dentre os Clupeiformes, as espécies piscívoras apresentam boca grande, com dentes bem desenvolvidos, e alcançam os maiores portes dentro de suas famílias (até $90 \mathrm{~cm}$ ). Registramos que o pristigasterídeo Chirocentrodon bleekerianus, um clupeiforme de pequeno porte (cerca de $10 \mathrm{~cm}$ ) do Atlântico Sul Ocidental, apresa peixes e camarões proporcionalmente grandes. Os peixes ingeridos ficam dobrados no estômago dessa sardinha, com suas cabeças e caudas em direção à cabeça do predador. Essa orientação distinta de presas também ocorre em algumas espécies piscívoras de Characiformes de pequeno a médio porte, que apresentam dentes caninos similares aos encontrados em C. bleekerianus.

Palavras-chave: Clupeiformes, hábitos predatórios, piscivoria, dobramento de presas, convergência.

\section{INTRODUCTION}

Most fish species of the order Clupeiformes (herrings and anchovies) feed on planktonic organisms. These plankton-eaters have long and numerous gill rakers and a small mouth with tiny teeth (Whitehead, 1973; Whitehead et al., 1988; Nelson, 1994). Predaceous fish-eaters are found in all clupeiform families but Denticipitidae (Whitehead, 1985; Whitehead et al., 1988; Nelson, 1994). Piscivorous herrings are among the largest species within their families and generally have a large mouth 
with well-developed teeth (Goulding, 1980; Whitehead, 1985; Nelson, 1994).

The pristigasterid dogtooth herring, Chirocentrodon bleekerianus, is a small-sized clupeiform, reaching $11 \mathrm{~cm}$ in total length (TL), found in the tropical SW Atlantic from the West Indies to southern Brazil (Whitehead, 1973; Figueiredo \& Menezes, 1978; Carvalho-Filho, 1994). We found no studies on the feeding habits of $C$. bleekerianus. However, its large mouth with welldeveloped and canine-like teeth (Whitehead, 1973) indicates that this herring may have piscivorous habits (Carvalho-Filho, 1994).

We analysed stomach contents of dogtooth herrings collected off the coast of Brazil, to examine the hypothesis that this small clupeid may prey on fishes. Although not intended as a dietary study, our results show that $C$. bleekerianus has predaceous habits and preys on fishes, an unrecorded habit among small species of clupeiforms (Whitehead, 1973, 1985; Nelson, 1994).

\section{MATERIAL AND METHODS}

We examined samples of $C$. bleekerianus collected with fence and trawl nets between $5: 30 \mathrm{~h}$ and 9:00 h, off the coast of São Paulo $(n=35)$, Espírito Santo, and Bahia $(\mathrm{n}=11)$, Brazil, in May and August 1996, and January 1997. Up on collection, the fish were fixed in $10 \%$ formalin and later preserved in $70 \%$ ethanol. Stomach repletion (SR) was visually estimated based on fullness state, using a four-point scale (Gramitto, 1999). Food items found in the stomach were examined under a stereomicroscope and clumped into two broad categories (fishes and shrimps), and their frequencies of occurrence were calculated (see Hyslop, 1980, for procedure). Standard length (SL) of the dogtooth herring and total length (TL) of undigested or partly digested prey were measured with tenths of millimeters precision (we used total instead of standard length for the prey animals, as both fishes and shrimps were found in stomachs). The position of fish prey in stomach was determined by opening the stomach wall in situ and making a sketch of the position of prey relative to the predator (Fig. 1). Voucher specimens and their stomach contents are in the Museu de História Natural, Universidade Estadual de Campinas (ZUEC 3398-3399, 3943-3948).

\section{RESULTS}

The examined $C$. bleekerianus specimens ranged from 51.9 to $93.0 \mathrm{~mm} \mathrm{SL}(\mathrm{x}=70.5$; $\mathrm{sd}=$ $10.2 ; n=46)$. Stomach repletion varied from SR2 (thick walls, small quantity of food) to SR4 (thin and stretched walls, stomach full of food), the latter condition representing $63 \%$ of the sample. Fishes and shrimps were found in 21 stomachs $(45.6 \%)$, fishes only were found in 17 stomachs (37\%), and shrimps only were found in eight stomachs (17.4\%). Fishes were distinctively folded in the stomachs, in $90.4 \%$ of the cases with their heads and tails pointing towards the predator's head (Fig. 1). The fish prey, mostly clupeiform larvae (Engraulidae and Clupeidae), were proportionally large and ranged from $22.7 \%$ to $48.7 \%(\mathrm{x}=36.2$; $\mathrm{sd}=7.3$; $\mathrm{n}=40$ ) of their predator's lengths (Fig. 2). The shrimps, mostly carideans (Penaeidae and Sergestidae), were smaller and ranged from $4.1 \%$ to $39.7 \%(\mathrm{x}=15 ; \mathrm{sd}=8.4, \mathrm{n}=46)$ of their predator's lengths (Fig. 2).

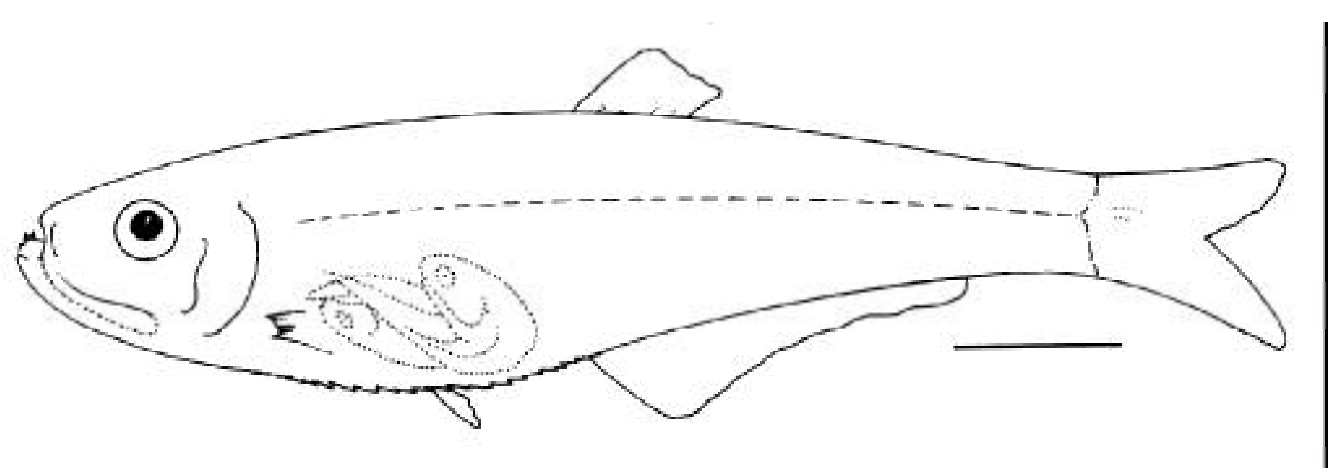

Fig. 1 - The distinctive folding and head-wards orientation of swallowed fish prey (dotted) in the stomach of Chirocentrodon bleekerianus (ZUEC 3943). Scale bar $=10 \mathrm{~mm}$. 


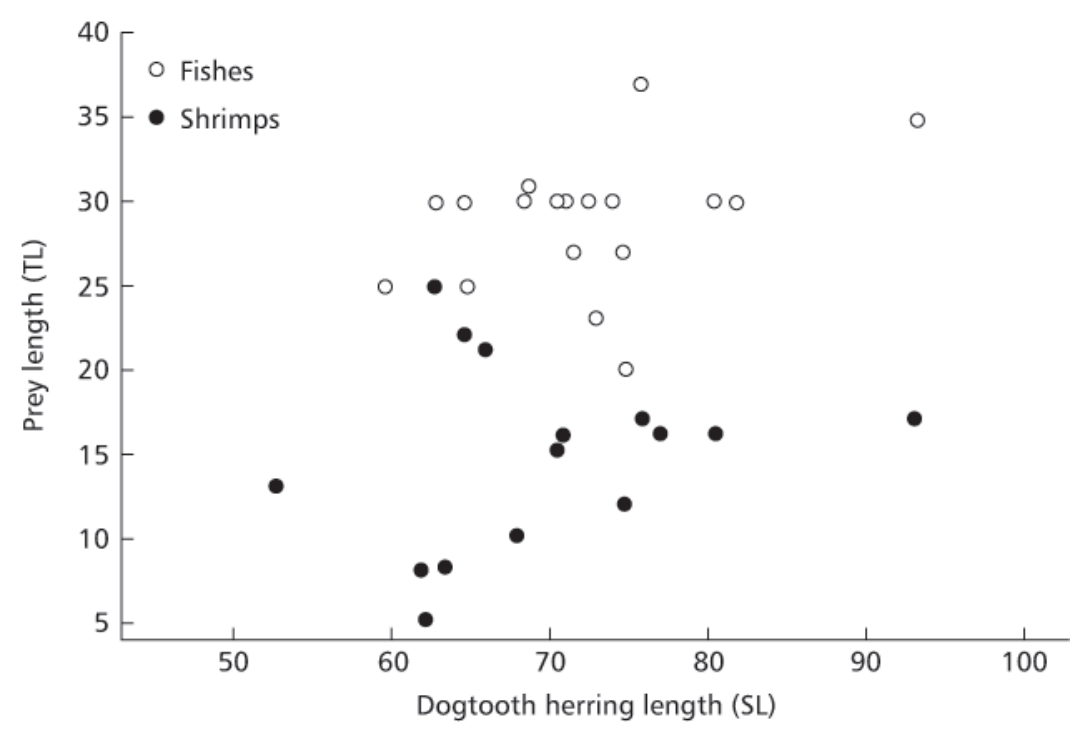

Fig. 2 - Relationship between total length of prey (TL in $\mathrm{mm}$ ) and standard length of Chirocentrodon bleekerianus (SL in $\mathrm{mm}$ ). Sample size: fish $(n=40)$, shrimps $(n=46)$.

\section{DISCUSSION}

The samples here studied confirmed our assumption that $C$. bleekerianus has predaceous habits and preys on fishes, an unrecorded habit among small species of clupeiforms (Whitehead, 1973, 1985; Nelson, 1994). Fish-eating clupeiforms generally reach sizes larger than the other species of this mostly plankton-eating group (Whitehead, 1985; Nelson, 1994). For example, the predaceous pristigasterid Pellona castelnaeana and the chirocentrid Chirocentrus dorab reach 55 and 90 cm TL respectively (Goulding, 1980; Luther, 1985; Nelson, 1994). The piscivorous engraulids Lycengraulis grossidens and Thryssa scratchleyi are among the largest representatives within the family, reaching 30 and $45 \mathrm{~cm}$ TL respectively (Figueiredo \& Menezes, 1978; Whitehead et al., 1988; Helfman et al., 1997). Thus, the pristigasterid C. bleekerianus, reaching about $10 \mathrm{~cm}$ TL, stands out as the only small-sized species among the predaceous fish-eating clupeiforms.

Chirocentrodon bleekerianus is able to prey on proportionally large fishes (up to about $50 \%$ of its own length) and its shrimp prey may reach a large size as well, an additional indication of its ability to handle large prey. The folded and distinctively oriented prey fish in the stomach of the dogtooth herring is probably due to the large size of this prey type. In the wolf herrings Chirocentrus dorab and C. nudus, large prey fish is found folded in the stomach (Luther, 1985) in a way similar to that recorded here for $C$. bleekerianus. The clupeids Cynothrissa and Odaxothrissa, the pristigasterid Chirocentrodon, the chirocentrid Chirocentrus, and the engraulid Lycothrissa, all have in common well developed canine-like teeth (Whitehead, 1973; Nelson, 1994). This is an unusual trait among clupeiforms and is likely related to a piscivorous diet. At least in Chirocentrus and Chirocentrodon, these teeth may play a role in folding and orientation of fish during prey handling and swallowing (shrimps, regardless of size, already have a propensity to fold).

Distinctively oriented folding of fish prey in the stomach is also recorded for the mainly piscivorous genera Cynopotamus, Galeocharax, and Acestrocephalus, of the large tropical freshwater order Characiformes (Menezes, 1976; IS, pers. obs.). These small to medium-sized characids (up to 25 $\mathrm{cm}$ TL) have curved and developed canine-like teeth on the premaxilla, and laminar and spiny gill rakers 
(Menezes, 1976). Folded fishes in the stomachs of these characids are oriented towards the predator's head in a way similar to that recorded here for Chirocentrodon (IS, pers. obs.). This type of prey folding and orientation is likely to occur during capture, with manipulation of prey before ingestion (Menezes, 1976), as headfirst swallowing is a common attribute among piscivorous fishes (Reimchen, 1991; Helfman et al., 1997). The distinctively oriented folding of prey fishes in smallsized clupeiform and characiform predaceous piscivores is a remarkable instance of convergence, as these two fish groups are phylogenetically unrelated (Nelson, 1994).

Acknowledgments - We thank João Luiz Gasparini and Guilherme E. L. Moura for helping with collection of specimens, Naércio A. Menezes for suggestions on the manuscript, Gustavo A. S. Melo for identification of shrimp prey, the Instituto Florestal (through Manoel A. Fontes) for the opportunity to study fishes in the Ilha Anchieta State Park, Esmeralda Z. Borghi for finishing our line drawings, Ibama for permits to collect marine fishes, and FAPESP, CNPq, and Finep/Pronex 97 for essential financial support.

\section{REFERENCES}

CARVAlHO-FILHO, A., 1994, Peixes: costa brasileira. São Paulo, Marca D’Água, 304p.

FIGUEIREDO, J. L. \& MENEZES, N. A., 1978, Manual de peixes marinhos do sudeste do Brasil. II. Teleostei (1). São Paulo, Museu de Zoologia Universidade de São Paulo, 110p.
GOULDING, M., 1980, The fishes and the forest: explorations in Amazonian natural history. Berkeley, University of California Press, 280p.

GRAMITTO, M. E., 1999, Feeding habits and estimation of daily ration of poor cod Trisopterus minutus capelanus (Gadidae) in the Adriatic Sea. Cybium, 23: 115-130.

HELFMAN, G. S., COLLETTE, B. B. \& FACEY, D. E., 1997, The diversity of fishes. Malden, Massachussets, Blackwell Science, 528p.

HYSLOP, E. J., 1980, Stomach contents analysis - a review of methods and their application. J. Fish Biol., 17: 411-429.

LUTHER, G., 1985, Food and feeding habits of the two species of Chirocentrus from Mandapan (India). Indian J. Fish., 32: 439-446.

MENEZES, N. A., 1976, On the Cynopotaminae, a new subfamily of Characidae (Osteichthyes, Ostariophysi, Characoidei). Arq. Zool. São Paulo, 28: 1-91.

NELSON, J. S., 1994, Fishes of the world (3rd ed.). New York, John Wiley \& Sons, 600p.

REIMCHEN, T. E., 1991, Evolutionary attributes of headfirst prey manipulation and swallowing in piscivores. Can. J. Zool., 69: 2912-2916.

WHITEHEAD, P. J. P., 1973, The clupeoid fishes of the Guianas. Bull. Brit. Mus. Nat. Hist. (Zool.), Suppl., 5: 1-227.

WHITEHEAD, P. J. P., 1985, FAO species catalogue. Vol. 7. Clupeoid fishes of the world (suborder Clupeoidei). Part 1. Chirocentridae, Clupeidae and Pristigasteridae. FAO Fish. Synopsis 125, part 1: 1-303.

WHITEHEAD, P. J. P., NELSON, G. J. \& WONGRATANA, T., 1988, FAO species catalogue. Vol. 7. Clupeoid fishes of the world (suborder Clupeoidei). Part 2. Engraulididae. FAO Fish. Synopsis 125, part 2: 305-579. 